\title{
Archaeological Reports
}

Published on behalf of the

The Society for the Promotion of Hellenic Studies

Editor

Richella Doyle, Society for the Promotion of Hellenic Studies, UK

Archaeological Reports is published by the Society for the Promotion of Hellenic Studies and the British School at Athens, for their subscribers. 'Archaeology in Greece', compiled annually by the Director of the British School at Athens, is the only account of recent archaeological work in Greece published in English. It is supplemented each year by a regional report on archaeology and research from other parts of the ancient Greek and Byzantine world: South Italy, Sicily, Sardinia, Albania, Cyprus, Asia Minor and the Black Sea are covered regularly. New acquisitions to UK antiquities' collections and their conservation also feature.

Archaeological Reports is only available with a subscription to The Journal of Hellenic Studies.

\section{To subscribe contact} Customer Services

\section{in Cambridge:}

Phone $+44(0) 1223326070$

Fax $+44(0) 1223325150$

Email journals@cambridge.org

\section{in New York:}

Phone +1 (845) 3537500

$\mathrm{Fax}+1(845) 3534141$

Email

subscriptions_newyork@cambridge.org

\section{Free email alerts}

Keep up-to-date with new material - sign up at

journals.cambridge.org/are-alerts 


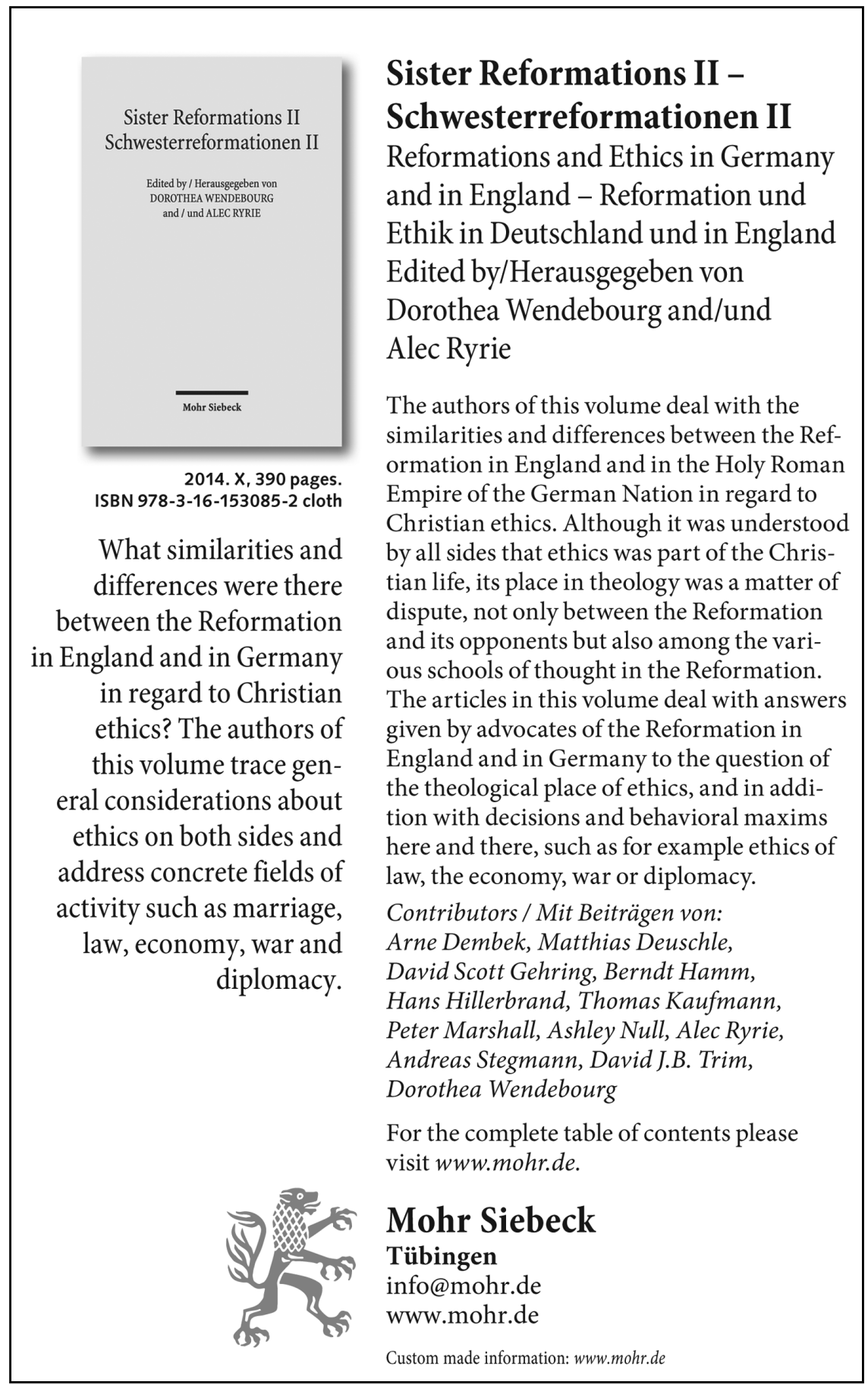




\section{The Classical Quarterly}

Published for The Classical Association

\section{Editors}

Bruce Gibson, University of Liverpool, UK

Andrew Morrison, University of Manchester, UK

The Classical Quarterly has a reputation for publishing the highest quality classical scholarship for over 100 years. It publishes research papers and short notes in the fields of language, literature, history and philosophy. Two substantial issues (around 300 pages each) of The Classical Quarterly appear each year, in May and December. Given the quality and depth of the articles published in The Classical Quarterly, any serious classical library needs to have a copy on its shelves.

\section{Price information}

is available at: http://journals.cambridge.org/caq

\section{Free email alerts}

Keep up-to-date with new material - sign up at http://journals.cambridge.org/caq-alerts

For free online content visit: http://journals.cambridge.org/caq

To subscribe contact Customer Services

\section{in Cambridge:}

Phone $+44(0) 1223326070$

$\mathrm{Fax}+44(0) 1223325150$

Email journals@cambridge.org

\section{in New York:}

Phone +1 (845) 3537500

Fax $+1(845) 3534141$

Email

subscriptions_newyork@cambridge.org 


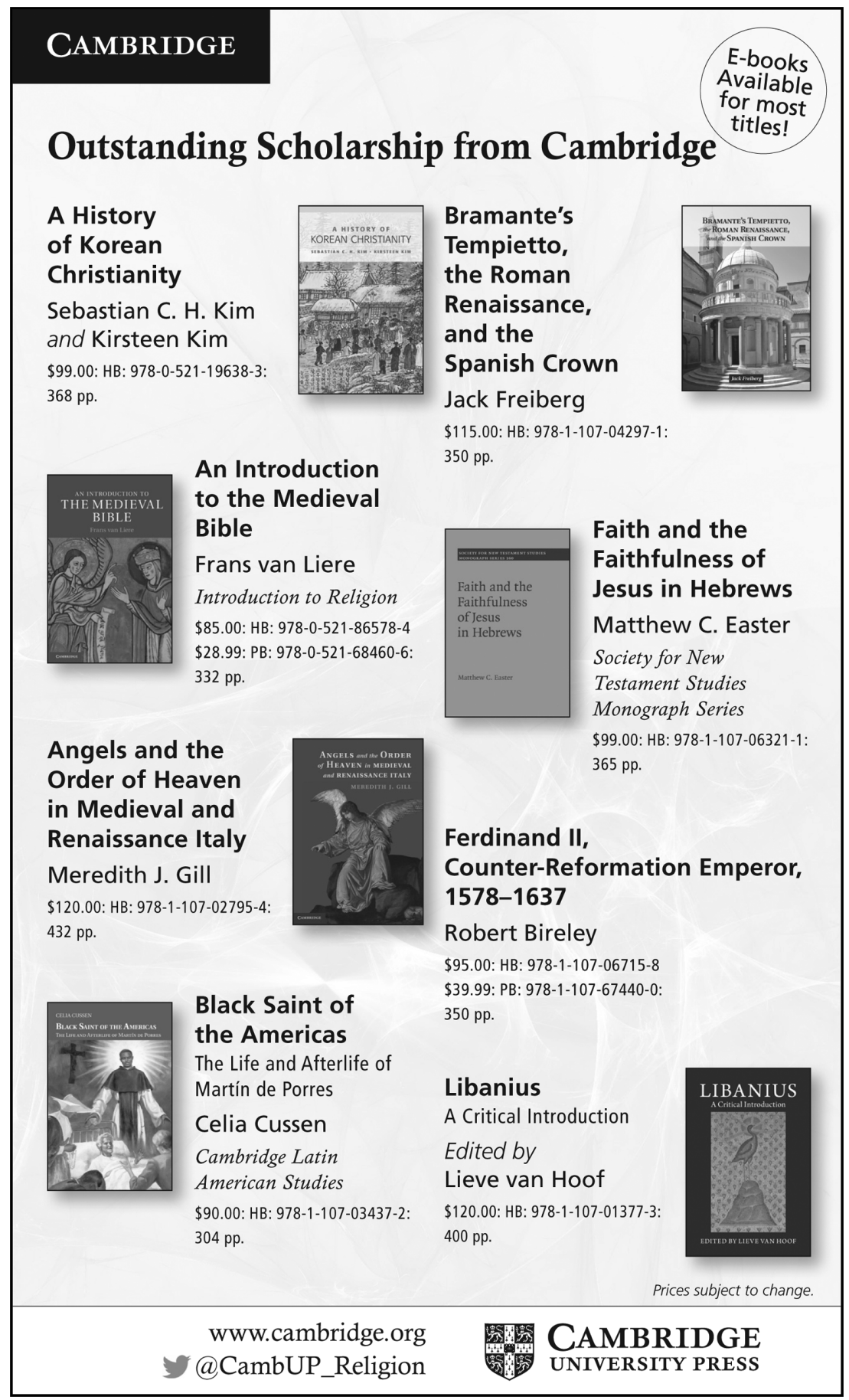




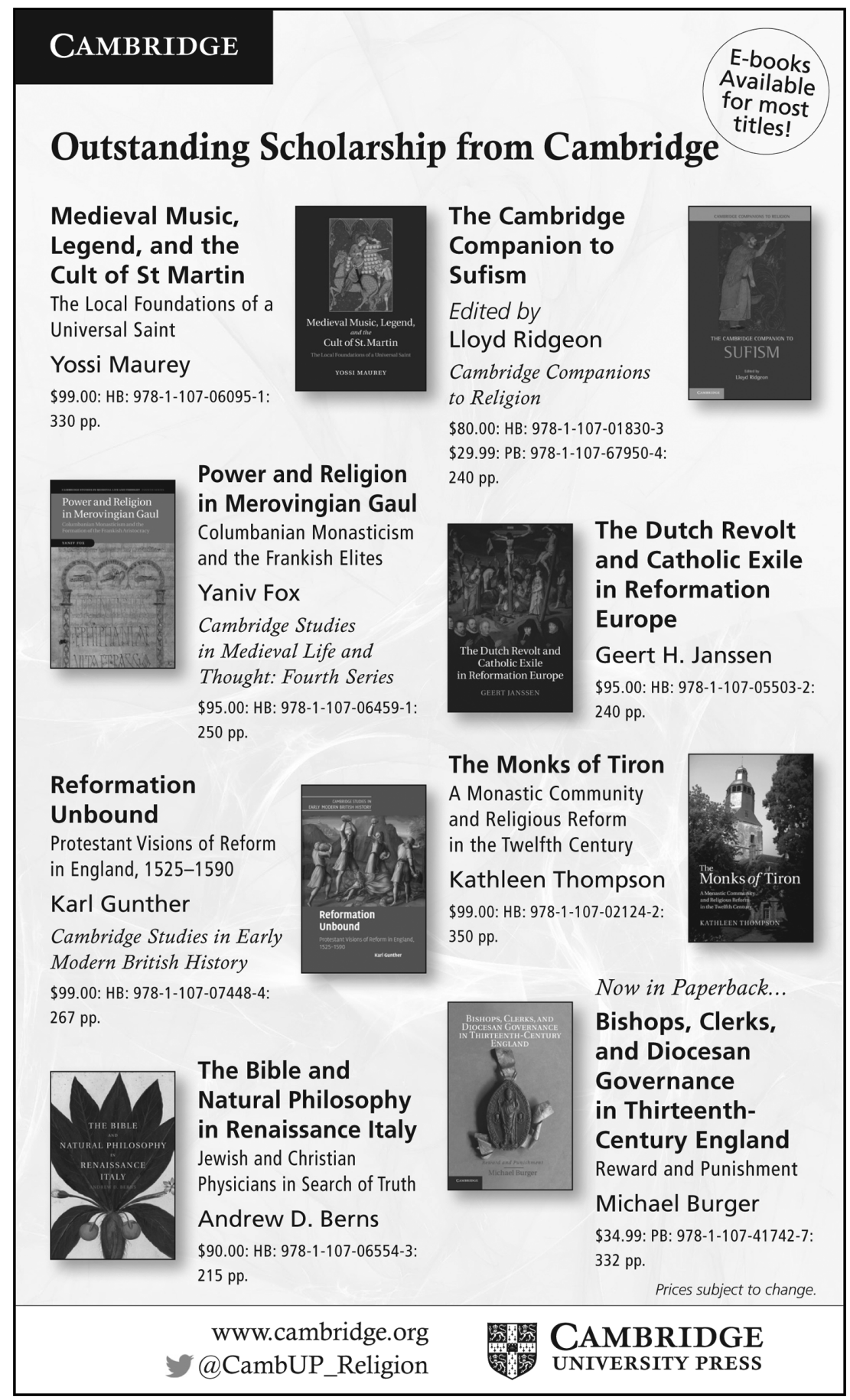




\section{Copying}

This journal is registered with the Copyright Clearance Center, 222 Rosewood Drive, Danvers, MA 01923, USA (www.copyright.com). Organizations in the USA who are also registered with CGC may therefore copy material (beyond the limits permitted by sections 107 and 108 of US copyright law) subject to payment to CCG. This consent does not extend to multiple copying for promotional or commercial purposes. Code 0022-0469/I4. ISI Tear Sheet Service, 350 Market Street, Philadelphia, PA I9I04, USA, is authorised to supply single copies of separate articles for private use only. Organizations authorized by the Copyright Licensing Agency may also copy material subject to the usual conditions. For all other use, permission should be sought from Cambridge or from the American Branch of Cambridge University Press.

This journal is included in the Cambridge Journals Online Service which can be found at www.journals.cambridge.org. For further information on other Press titles access www.cambridge.org.

This journal issue has been printed on FSC-certified paper and cover board. FSC is an independent, non-governmental, not-for-profit organization established to promote the responsible management of the world's forests. Please see www.fsc.org for information.

(C) Cambridge University Press, 2014

CAMBRIDGE UNIVERSITY PRESS

The Edinburgh Building, Cambridge $\mathrm{CB}_{2}$ 8RU, United Kingdom

32 Avenue of the Americas, New York, NY ioor3-2473, USA

477 Williamstown Road, Port Melbourne, VIC 3207, Australia

C/ Orense, 4, planta 13, 28020 Madrid, Spain

Dock House, The Waterfront, Cape Town 8oor, South Africa 


\section{The Journal of Ecclesiastical History}

\section{Contents}

\section{ARTICLES}

Did the English Really Think They Were God's Elect in the Anglo-Saxon Period?

George Molyneaux

Pope Alexander VI, Slavery and Voluntary Subjection: 'Ineffabilis et Summi Patris' in Context

Hector Avalos

A Moderate Puritan Preacher Negotiates Religious Change

AnN Hughes

Methodist Spiritual Condition in Georgian Northern England

Robert A. SCHOFIELD

William McIlwaine and the 1859 Revival in Ulster: A Study of Anglican and Evangelical Identities

DANIEL RitchiE

False Start or Brave Beginning? The Society of Jews and Christians, 1924-1944

ANNE Summers

\section{REVIEW ARTICLES}

Demythologizing Wealth: The Transformations of Christian Late Antiquity

RICHARD FINN

What Caused Iconoclasm?

JUDITH HERRIN

REVIEWS

Books REGEIVED

The Eusebius Essay PRIZE

Authors' AdDresses 